\title{
NO, YOU WOULDN'T WANT TO \\ NOT READ THIS PAPER: \\ a working paper on a typology of negation \\ across the romance languages
}

\author{
Bryan Fleming Danielle Belko Jeffrey Nagengast
}

I. INTRODUCTION:

SO YOU WON'T NOT KNOW WHAT WE'RE NOT GOING TO NOT DO

We know that the world's languages have different strategies for forming negative sentences, and these strategies can vary greatly from language family to language family. In this paper, we discuss negation in several languages of the same family-languages which are strikingly similar in many aspects but which use varying strategies to form negatives.

We begin our discussion by describing Rafaella Zanuttini's investigation into the typology of Romance languages (RL) in terms of how negation is formed. We follow with a more detailed description of negation strategies in several widely spoken romance languages, viz., Spanish, Italian, and French-bringing in information from other dialects when useful or interesting. Next, we attempt to discuss Zanuttini's typology vis-àvis the corpora of data we have in the aforementioned languages, citing the (in)compatibility/(non-)compliance of these languages with her typological descriptions. Lastly, we will discuss some historical insight into why these differences exist and follow that with descriptions of languages and dialects not referenced in Zanuttini's article. We will also discuss any trends that these languages exhibit in relation to Zanuttini's generalizations. 


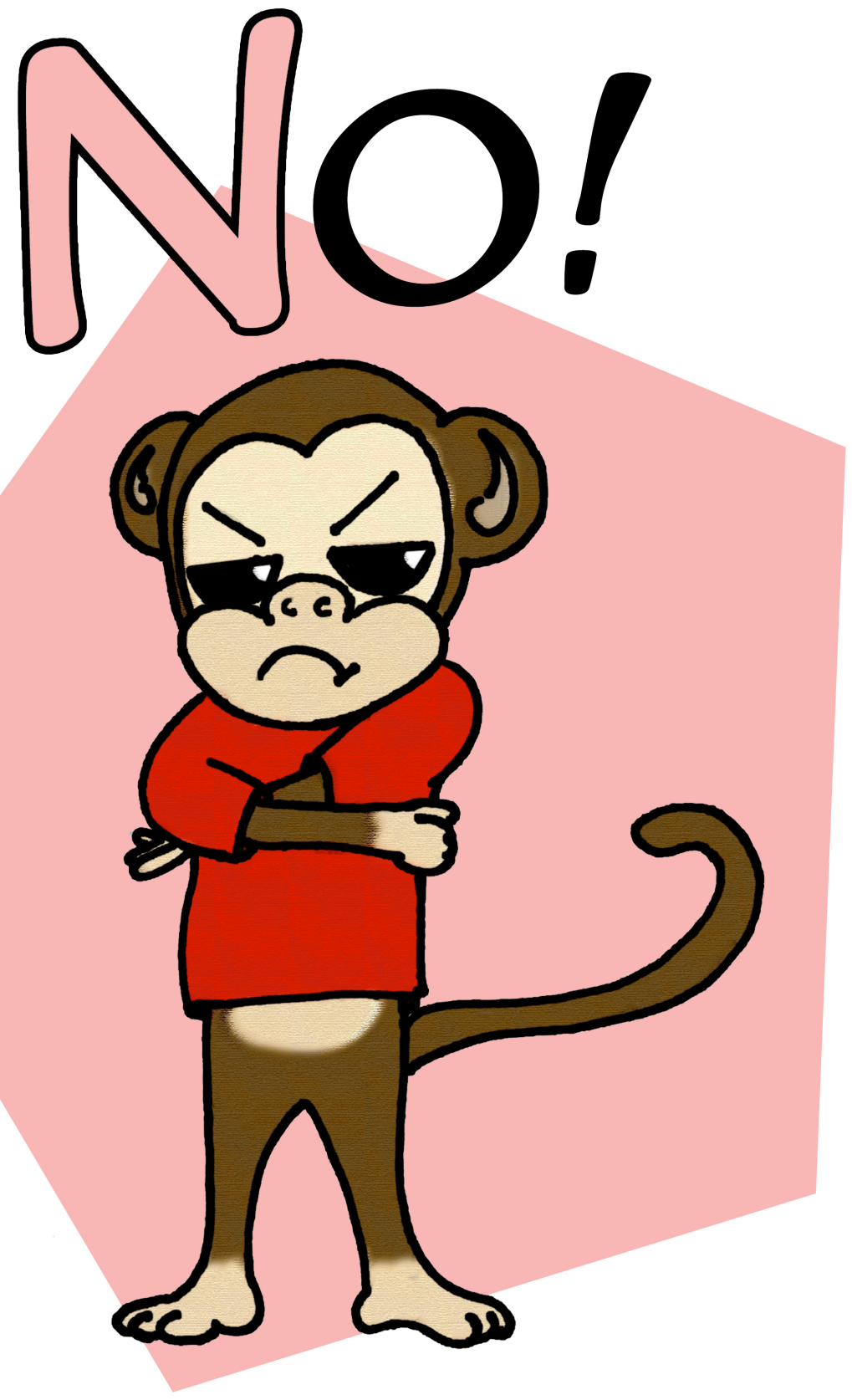


TABLE OF ABBREVIATIONS

\begin{tabular}{|l|l|}
\hline Abbreviation & Meaning \\
\hline *** & ungrammatical \\
\hline $\mathrm{I}, 2,3$ & first, second, third person \\
\hline ART & article \\
\hline AUX & auxiliary \\
\hline Ca & Used for numbering examples of Catalan \\
\hline CL & clitic \\
\hline COMP & comparative marker \\
\hline COND & Conditional \\
\hline EXPL & expletive \\
\hline F & Feminine \\
\hline F/Fr & Used for numbering examples of French \\
\hline FUT & future tense \\
\hline I/It & Used for numbering examples of Italian \\
\hline IMP & imperative \\
\hline IMPRF & imperfective \\
\hline INF & infinitive \\
\hline M & masculine \\
\hline MSF & Modern Standard French \\
\hline NEG & negative marker \\
\hline NI & negative indefinite \\
\hline OBJ & object \\
\hline Pa & Used for numbering examples of Waldensian Patouà \\
\hline P & plural \\
\hline PART & partitive \\
\hline PPL & past participle \\
\hline PREP & preposition \\
\hline PRES & present tense \\
\hline PST & past tense \\
\hline RC & Used for numbering examples of Roussillon Catalan \\
\hline RFL & reflexive \\
\hline RL & Romance Languages \\
\hline S & singular \\
\hline S/Sp & Used for numbering examples of Spanish \\
\hline Si & Used for numbering examples of Sicilian \\
\hline SUB & subject \\
\hline SUBJ & subjunctive \\
\hline Ve & Used for numbering examples of Venetian \\
\hline W/Wa & \\
\hline X & Used for numbering examples of Walloon \\
\hline & \\
\hline
\end{tabular}


Who is Zanuttini; and why don't we not care?

In her article, Negation and verb movement, Raffaella Zanuttini (I997b) gives us a detailed typological description of several aspects of negation in RL. Her typology begins by dividing the negative markers found in RL into two classes: pre-verbal and post-verbal. From these two classes, she describes three strategies used by RL in forming sentential negation: Group I - negative markers in pre-verbal position, which can alone negate sentences; Group 2 - negative markers in post-verbal position, which can alone negate sentences; and Group 3 - negative markers co-occurring in both pre-verbal and post-verbal positions. ${ }^{\mathrm{I}}$

Group I: PRE-VERBAL

X.I (Zanuttini I997a: 3ff)

\begin{tabular}{|c|c|c|c|c|c|c|c|}
\hline a) & $\begin{array}{l}\text { Gianni } \\
\text { Gianni }\end{array}$ & $\begin{array}{l}\text { non } \\
\text { NEG }\end{array}$ & $\begin{array}{l}\text { ha } \\
\text { AUX }\end{array}$ & $\begin{array}{l}\text { telefonato } \\
\text { phone.PPL }\end{array}$ & $\begin{array}{l}\text { a } \\
\text { PREP }\end{array}$ & $\begin{array}{l}\text { sua } \\
\text { his }\end{array}$ & $\begin{array}{l}\text { madre. } \\
\text { mother }\end{array}$ \\
\hline b) & $\begin{array}{l}\text { Juan } \\
\text { Juan }\end{array}$ & $\begin{array}{l}\text { no } \\
\text { NEG }\end{array}$ & $\begin{array}{l}\text { ha } \\
\text { AUX }\end{array}$ & $\begin{array}{l}\text { llamado } \\
\text { call.PPL }\end{array}$ & $\begin{array}{l}\mathrm{a} \\
\text { PREP }\end{array}$ & $\begin{array}{l}\text { su } \\
\text { his }\end{array}$ & $\begin{array}{l}\text { madre. (Spanish) } \\
\text { mother }\end{array}$ \\
\hline c) & $\begin{array}{l}\text { El } \\
\text { DET }\end{array}$ & $\begin{array}{l}\text { Joan } \\
\text { Joan }\end{array}$ & $\begin{array}{l}\text { no } \\
\text { NEG }\end{array}$ & $\begin{array}{l}\mathrm{a} \\
\mathrm{A} U X\end{array}$ & $\begin{array}{l}\text { trucat } \\
\text { call.PST }\end{array}$ & $\begin{array}{l}\mathrm{a} \\
\text { PREP }\end{array}$ & $\begin{array}{l}\text { sa mare. (Catalan) } \\
\text { his mother }\end{array}$ \\
\hline d) & $\begin{array}{l}\text { João } \\
\text { João }\end{array}$ & $\begin{array}{l}\text { não } \\
\text { NEG }\end{array}$ & $\begin{array}{l}\text { ligou } \\
\text { call.PST }\end{array}$ & $\begin{array}{l}\text { para } \\
\text { PREP }\end{array}$ & $\begin{array}{l}\text { sua } \\
\text { his }\end{array}$ & $\begin{array}{l}\text { mãe. } \\
\text { mother }\end{array}$ & (Portuguese) \\
\hline & $\begin{array}{l}\text { Jon } \\
\text { Jon }\end{array}$ & $\begin{array}{l}\text { nu-i } \\
\text { NEG }\end{array}$ & & $\begin{array}{l}\text { telefona } \\
\text { phone.PST }\end{array}$ & & $\begin{array}{l}\text { mamei } \\
\text { mother }\end{array}$ & $\begin{array}{l}\text { lui. (Romanian) } \\
\text { his }\end{array}$ \\
\hline
\end{tabular}

'John hasn't called his mother.'

Group 2: POST-VERBAL

X.2

$\begin{array}{llll}\text { Maria } & \text { a } & \text { mangia } & \text { nen. (Piemontese) } \\ \text { Maria } & \text { S.CL } & \text { eat.PRES } & \text { NEG } \\ \text { 'Maria doesn't eat' } & & \end{array}$

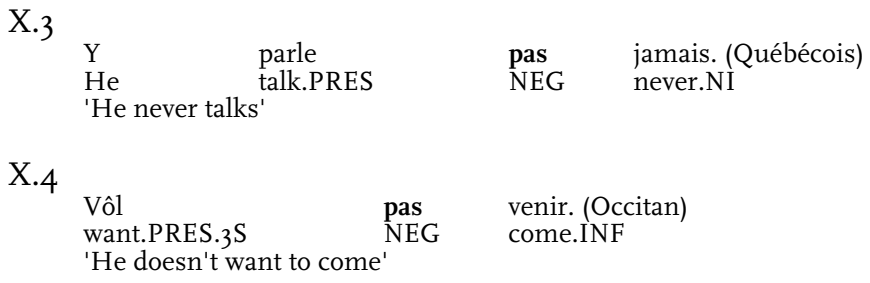

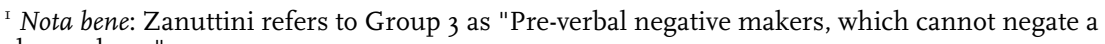
clause alone."

${ }^{2}$ Throughout this document, the glosses have been provided by Belko, Fleming, and Nagengast; any mistakes are our own.

${ }^{3}$ Per Prof. Sheila McIntosh, $s a$ is attributed to people from the Balearic Islands-in contrast to the standard, seva.
} 
X.5

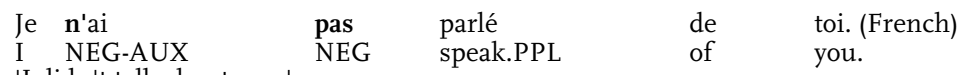

X.6

Po $n^{\prime} m u$ nin tromper. (Walloon)

for NEG-me NEG err.INF

'so that I don't make a mistake.'

In this paper, we would like to discuss four typological generalizations that Zanuttini presents in her article (I997b) regarding: I) negatives and pronominal clitics; 2) negative imperatives; 3) negative indefinites; and 4) negation and yes-no questions. Although she initially breaks up the Romance Languages into the three groups listed above, she focuses her descriptions on languages in Groups I and 3. For organizational purposes, we will first discuss how languages in Group I and 3 accord with her suppositions, and later focus on Group 2 languages and how they fit into this system. Here, we introduce Zanuttini's typological descriptions.

Zanuttini first addresses the location of negative markers in relation to pronominal clitics in pre-verbal position. She claims that "the pre-verbal negative markers which can negate a clause alone, for example Italian non, Spanish no and Portuguese nãa, always occur to the left of a string of pronominal clitics in pre-verbal position" (Ibid.: 2I7). She exemplifies this with Spanish, a Group I language, that places its negative marker no before the indirect and direct pronominal clitics, se and lo respectively.

X.7

\begin{tabular}{|c|c|c|c|c|c|}
\hline Maria & no & & lo & & (Spanish) \\
\hline Maria & $\begin{array}{l}\text { NEG } \\
\text { give it t }\end{array}$ & him & it & give.PST & \\
\hline
\end{tabular}

On the other hand, negative markers in Group 3 languages "do not systematically precede a string of pronominal clitics in preverbal position. While some do, others precede pronominal clitics of third person, the partitive, and the locative clitic, but follow pronominal clitics of first and second person as well as reflexives" (Ibid.: 2I7). She gives several examples of Cairese, a Piedmontese dialect, where the location of the negative marker is dependent on the person of the pronominal clitic. In (X.8), the negative marker precedes the third person pronominal clitic li/la, while in (X.9) it follows the first/second person marker mi/ti.

X.8

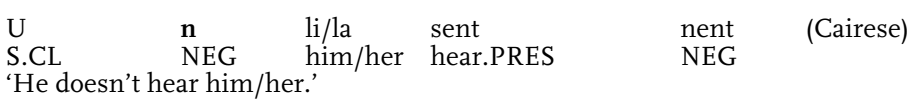

X.9

$\begin{array}{lllll}\text { U } & \text { min/tin } & \text { sent } & \text { nent. } & \text { (Cairese) } \\ \text { S.CL } & \text { me-NEG/you-NEG } & \text { hear.PRES } & \text { NEG } & \end{array}$

'He doesn't hear me/you.'

Her second generalization concerns negative imperatives for the informal second person singular. According to her article, the negative 
marker in Group I languages "cannot occur in imperative clauses which employ a verbal form unique to the imperative paradigm" (Ibid.: 218). This means that the same verb form that is used to create a positive imperative (for the informal second person singular only) cannot be used to form the negative counterpart. Languages utilize verb forms such as the subjunctive when forming a negative command. In the Spanish example below (X.IO), the verb form in the positive command, habla, renders a sentence ungrammatical in the negative command (X.Iob). Instead the subjunctive form of the verb is used (X.IOc). ${ }^{4}$

X.IO

a) Habla! (Spanish)

talk.IMP.2S

Talk!

b) $* * *$ No habla!

NEG talk.IMP.2S

'Don't talk!'

c) No hables!

NEG talk.IMP.SUBJ.2S

'Don't talk!'

Group 3 languages, contrastingly, do not show the same differences between the positive and negative second person singular imperatives. Zanuttini argues, "In some cases, [pre-verbal negative markers] co-occur with imperative verbal forms...[while] in other cases, as for example in Cairese (a dialect of Piemontese from Cairo Montenotte, cf. Parry I985), they simply do not occur with non-finite forms, leaving the function of negating the clause entirely to the post-verbal negative element, which can freely co-occur with a verbal form unique to the imperative" (Zanuttini I997b: 218-2I9). She gives the example in Walloon (X.II), where the pre-verbal negative $n u$ does not require a change of the imperative verb form. ${ }^{5}$

$\begin{array}{llll}\text { X.II } & & & \\ \text { Nu } & \text { l'houke } & \text { nin! } & \text { (Walloon) } \\ \text { NEG } & \text { him-call.IMP } & \text { NEG } & \\ \text { 'Don't call him!' } & \end{array}$

Her third typological claim concerns the distribution of negative indefinites (never, nothing, no-one, etc.). In Group I languages, "negative indefinites in post-verbal position must co-occur with a negative element in

\footnotetext{
${ }^{4}$ Zanuttini (I997b: 2I8) claims: "a negative marker can be followed by an auxiliary verb, in turn followed by the main verb in the form of an infinitive or a gerund." She goes on to give examples of negative imperatives from Frulian, Portuguese and Tarantino, without, however, their positive counterparts. It would be helpful to see the positive imperatives, in order to determine if the auxiliary is always present, or simply added to the negative form. We do not have enough information, nor do we clearly understand her reasoning on this point to discuss it in great depth. We will therefore focus on imperatives without auxiliary verbs.
}

${ }^{5}$ Again Zanuttini does not give an example of the positive imperative, therefore we must assume that the imperative verb form is the same for both positive and negative commands. 
pre-verbal position" (Ibid.: 219). Accordingly, in Spanish, a Group I language, a negative indefinite that follows the verb, must co-occur with the pre-verbal negative marker no (X.I2a). If the pre-verbal negative is absent, the resulting sentence is ungrammatical (X.I2b).

X.12

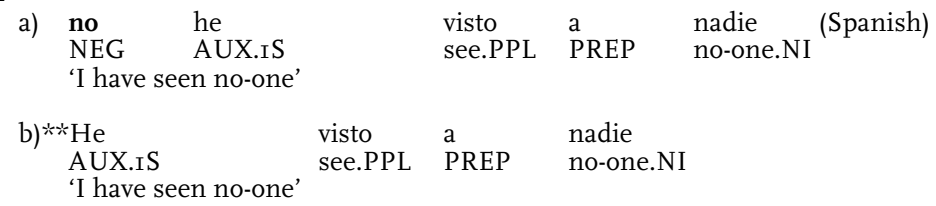

Contrastingly, languages in Group 3 do not adhere to the same constraints. "In these languages, it is possible to find them in post-verbal position in the absence of a negative element co-occuring in pre-verbal position" (Ibid.: 220). Languages in this group would be similar to Standard English in the sense that "I saw no one" would be grammatical, where no negative marker is needed before the verb in the presence of the post-verbal negative indefinite no one.

Zanuttini's last point involves pre-verbal negative markers and yes/no questions. In Group I languages, the pre-verbal negative prevents subject-verb inversion in question formation, which is possible without the pre-verbal negative. "A question is formed by maintaining the same wordorder found in non-interrogative clauses, where the negative marker precedes the subject clitic, which in turn precedes the finite verb" (Ibid.: 22I). She uses a Paduan example, where in the absence of a pre-verbal negative, a question can be formed by inverting the subject (e)l and the verb, vien (X.13b). The pre-verbal negative, however, makes this inversion impossible, as seen in (X.I3c). In order to form a question with a preverbal negative, the word order of the original declarative is maintained (X.I3d).

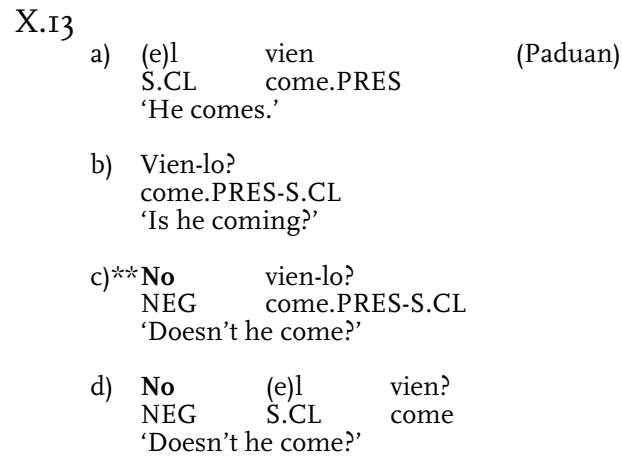

Languages in Group 3, on the other hand, "show inversion of the verb around the pronominal subject" (Ibid.: 222). Indeed, in (X.I4) below, we see that to form a question, the subject pronoun $i l$, which is before the verb, est, in (X.I4a), is inverted and follows the verb in (X.I4b). This same inversion also occurs in the presence of a pre-verbal negative marker (X.I4c). 
X.I4

a) Il est heureux.

S happy

b) Est-il heureux?

Be.3S-he happy

'Is he happy?'

c) N'est-il pas heureux?

NEG-be.3S-he NEG happy.

'Isn't he happy?'

\section{NEGATION IN LANGX}

I. Spanish

Basic Spanish negation is achieved by placing the sentential negator no at the beginning of the entire verb nucleus. This gives us the basic Spanish negation pattern of no V. Compare the following sentences:

S.I

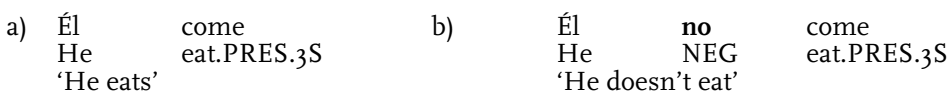

If the negative occurs in the subordinate clause, no still precedes the verb that is being negated within the clause. In (S.2) below, the matrix clause verb querer is not being negated. No acts only upon the main verb in the subordinate clause, coma.

S.2

$\begin{array}{llllll}\text { Beatriz } & \text { quiere } & \text { que } & \text { él } & \text { no } & \text { coma. } \\ \text { Beatriz } & \text { want.PRES.3S } & \text { that } & \text { he } & \text { NEG } & \text { eat.SUBJ.3S } \\ \text { 'Beatriz wants him not to eat' } & & & & \end{array}$

In verbal constructions that utilize an auxiliary, the no likewise precedes the entire verb nucleus and cannot separate the two-part verbal construction.

S.3

$\begin{array}{llll}\text { Él } & \text { no } & \text { ha } & \text { comido } \\ \text { He } & \text { NEG } & \text { AUX.3S } & \text { eat.PPL }\end{array}$

'He has not eaten.'

b) **él ha no comido

$\mathrm{He} \quad \mathrm{AUX} .3 \mathrm{~S} \quad \mathrm{NEG}$ eat.PPL

'He has not eaten.'

In standard Spanish, the pre-verbal no generally co-occurs with post-verbal negative indefinites such as nunca, nada, nadie, ('never,' 'nothing,' 'no-one'), etc. The absence of the pre-verbal no renders the sentence ungrammatical. 
a) Alicia no trabaja nunca

Alicia NEG, work.PRES.3S never.NI

'Alicia never works.'

b) **Alicia trabaja nunca

Alicia work.PRES.3S never.NI

'Alicia never works.'

When the negative indefinite appears pre-verbally, the sentence negater no is not required. The presence of no would in fact produce a double negative reading (Giannakidou, 23).

S.5 (Giannakidou)
a) Nadie
No-one.NI AUX.
'No one has seen Pedro.'
ha
visto a Pedro
see.PPL PREP Pedro

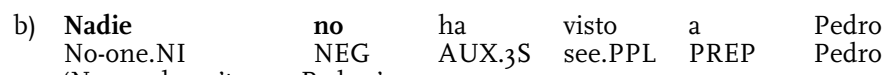
'No one hasn't seen Pedro.'

While the addition of no in the above example produces a double negative, there are certain environments in which no can be present but not result in a negative reading. This expletive negation, similar to the pleonastic ne in French, is licensed under the scope of verbs of fear and doubt, for example, which are all nonveridical with respect to the proposition expressed in the subordinate clause (Espinal, 2000a: 6I). In (S.6), the presence of no is optional and does not change the meaning of the subordinate clause.

\begin{tabular}{|c|c|c|c|c|c|}
\hline $\begin{array}{c}\text { S.6 (Espinal) } \\
\text { Hay } \\
\text { Is-there }\end{array}$ & $\begin{array}{l}\text { quién } \\
\text { who }\end{array}$ & $\begin{array}{l}\text { dude } \\
\text { doubt.SUBJ.3S }\end{array}$ & $\begin{array}{l}\text { que } \\
\text { that }\end{array}$ & $\begin{array}{l}\text { (no) } \\
\text { NEG }\end{array}$ & $\begin{array}{l}\text { son } \\
\text { be.PRES. } 3 \text { P }\end{array}$ \\
\hline $\begin{array}{l}\text { falsas } \\
\text { false }\end{array}$ & & & $\begin{array}{l}\text { tales? } \\
\text { stories }\end{array}$ & & \\
\hline
\end{tabular}

Returning to negative indefinites, it is interesting to note that, when in post-verbal position, they can appear as complements of negative prepositions, negative embedding predicates and adversative predicates, certain emotive predicates, and comparative-like contexts (Herburger, 297). It is suggested that they are to be interpreted merely as existential quantifiers as they cannot contribute to negation in their own right. As seen in the translations (S.7a-c), nada, nadie, and nunca are not interpreted as being overtly negative.

S.7 (Herburger)

a) Antes de hacer nada,

Before of do.INF nothing-NI

$\begin{array}{llll}\text { debes } & \text { lavarle } & \text { las } & \text { manos } \\ \text { must.PRES.2S } & \text { wash.INF.CL } & \text { the } & \text { hands }\end{array}$

'Before doing anything, you should wash his hands.'

b) Prohibieron que saliera nadie

Prohibit.PST.3P that , leave.SUBJ.3S no-one.NI 
In contrast, conditional sentences do not allow for the presence of negative indefinites, as seen in S.8b (Herburger, 299).

\section{S.8 (Herburger)}

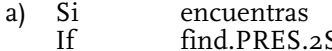
'If you find anything, tell me.'
algo avísame
something tell.IMP.3S.me
b) $* * \mathrm{Si} \quad$ encuentras
'If you find anything, tell me.'

$\begin{array}{ll}\text { nada } & \text { avísame } \\ \text { nothing.NI } & \text { tell.IMP.3S.me }\end{array}$

With respect to negative imperatives, no functions as expected and always precedes the verb nucleus. In the second person informal singular imperative, the negator requires the presence of a form different than that of the positive imperative: in all cases, the subjunctive.

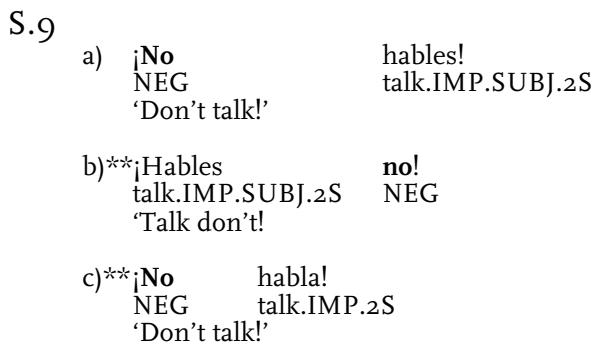

\section{Italian}

Italian also utilizes a pre-verbal negation system. The negative marker non always precedes the main verb of a clause. The basic structure, therefore, of sentential negation is non + V. In the example (I.Ib) below, the negative non precedes the main verb legge. In standard Italian, placing the non after the main verb renders the sentence infelicitous.

I.I

a) Lui legge.

$\mathrm{He}$ read.PRES.3S

'He reads well.'

b) Lui non legge.

$\mathrm{He} \quad$ NEG read.PRES.3S

'He does not read well.'

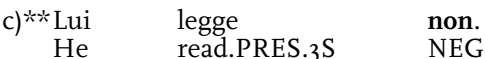

'He reads not.'

It is interesting to note that it is possible to find the non following the verb if there is an adjunct such as an adverb, a direct object, or a prepositional phrase also following the verb. In these instances however, 
the negative marker is acting upon the adjunct and not the verb, keeping the overall sentence positive. When adding the adverb bene 'well' to the above sentence, the negative marker can precede bene, but then the focus is shifted to the adverb (I.2b). (I.2c) and (I.2d) are also plausible utterances, with a negative marker following the verb but preceding a direct object or a prepositional phrase, respectively; however, they suggest the existence of a subsequent contrastive clause.

I.2

a) Lui legge bene.

$\mathrm{He}$ read.PRES.3S well

'He reads well.'

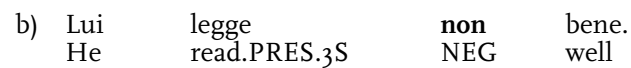

'He reads not well.'

c) Lui legge non libri.

$\mathrm{He}$ read.PRES.3S NEG book.PL

'He reads not books (but magazines, newspapers, etc).'

$\begin{array}{lllll}\text { d) Lui } & \text { legge } & \text { non } & \text { con } & \text { Paolo. } \\ \text { He read.PRES.3S } & \text { NEG with } & \text { Paolo } \\ \text { 'He reads not with Paolo (but with Maria).' } & \end{array}$

If the negative occurs in the subordinate clause, non still precedes the verb that is being negated within the clause. In the (I.3) below, the matrix clause verb vuole is not being negated, but rather the main verb in the subordinate clause vada. Therefore, non precedes vada.

I.3

$\begin{array}{llllll}\text { 'Lei vuole } & \text { che lui } & \text { non } & \text { vada } & \text { via. } \\ \text { She want.PRES.3S that } & \text { he } & \text { NEG } & \text { go.PRES.SUBJ.3S } & \text { away } \\ \text { 'She wants that he not go away.' } & & & & \end{array}$

When a sentence contains an auxiliary verb in addition to the 'main' verb, the negative marker precedes the auxiliary.

I.4

Tomaso AUX.3S write.PPL a book

$\begin{array}{llllll}\text { b) Tomaso } & \text { non } & \text { ha } & \text { scritto } & \text { un } & \text { libro. } \\ \text { Tomaso } & \text { NEG } & \text { AUX.3S } & \text { write.PPL } & \text { a } & \text { book }\end{array}$

'Tomaso has not written a book.'

One interesting aspect about Italian negation is that "non can follow verbs which do not take any overt complementizer in their complement" such as the modal verbs potere, volere, and dovere-'can', 'want', and 'must' (Kim: I64). Therefore, in a modal construction like (I.5), non can come in between the modal verb potrebbe, and the complement aver (Ibid.).

I. 5 (Kim:I64)

Gianni

potrebbe

non

aver

mai

Gianni can.COND NEG have.INF never.NI

parlato.

'Gianni could not (to) have spoken ever.

speak.PPL 
In standard Italian, the pre-verbal non MUST co-occur with postverbal negative indefinites, such as mai, niente, nessuno, ('never,' 'nothing,' 'no-one'), etc. The absence of the pre-verbal non renders the sentence ungrammatical.

I.6

a) Non ho comprato niente.

NEG AUX.IS buy.PPL nothing.NI

'I didn't buy anything.' (Lit. 'I did not buy nothing')

b) $* *$ Ho comprato niente.

AUX.IS buy.PPL nothing.NI

'I bought nothing.'

When the negative indefinite is in pre-verbal position, however, the non is not necessary. Nota bene: inversion of the verb and the object, as seen in I.7a, is not very common in Standard Italian, although it is not considered incorrect.

I.7

a) Niente ho comprato

Nothing.NI AUX.IS buy.PPL

'Nothing I have bought'

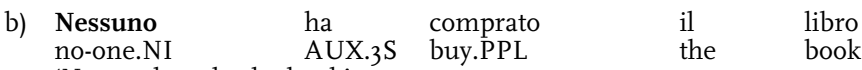

'No-one bought the book'

It is important to note that the presence of non does not always imply negation. There are a few instances where non acts as a pleonastic element in a sentence. One such situation is in comparative clauses, which is comparable to the pleonastic ne in French. In standard Italian there are several ways to construct a comparative clause. I.8 below shows a variety of ways in which Italian can express 'he arrived earlier than I expected.' The non in I.8a and I.8b does not negate the verb aspettassi, but instead adds emphasis to the comparison.

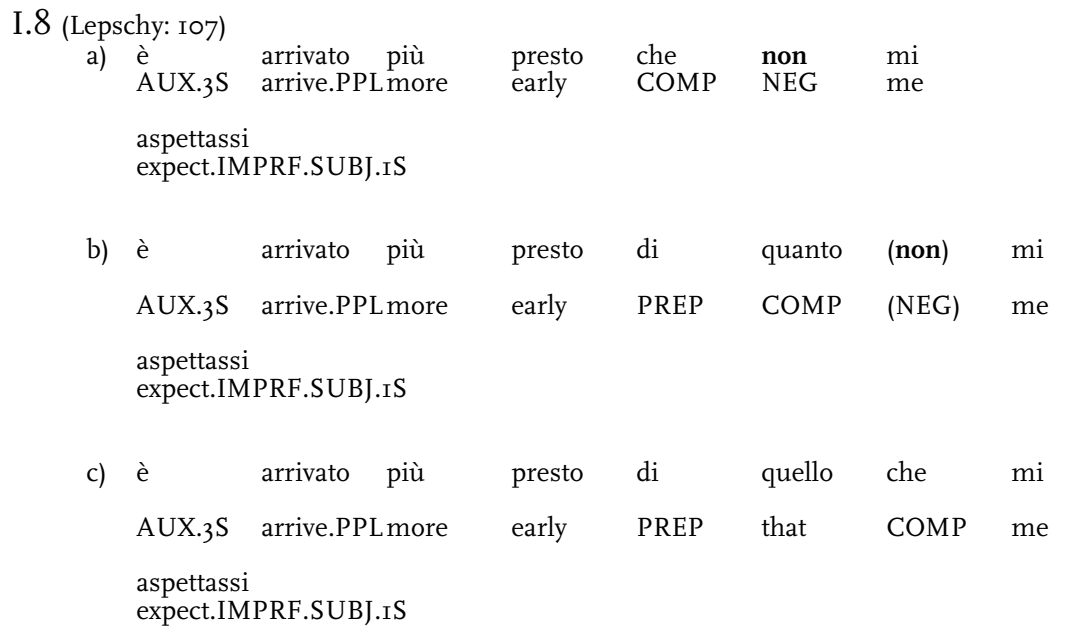

'He arrived earlier than I expected.' 


\section{French}

Sentential negation in Modern Standard French (MSF) is produced by using two co-occurring particles, ne and pas, which, in general terms, circumscribe an inflected verb. $\mathrm{Ne}$ is always preverbal, and pas is post-verbal in most cases. More succinctly, this description provides us with the following basic structure of sentential negation in French: ne V pas.

F.I

$\begin{array}{lllll}\text { Il } & \text { ne } & \text { mange } & \text { pas } & \text { assez. } \\ \text { 3S.M } & \text { NEG } & \text { eat.3S } & \text { NEG } & \text { enough }\end{array}$

Before vowels, $n e$ is cliticized as $n$ '.

F.2

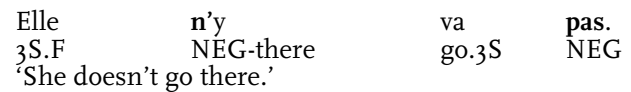

In compound tenses, ne preceeds an AUX, which is, then, immediately followed by pas, in accordance with our description that ne...pas circumscribes an inflected verb.

F.3

$\begin{array}{llrl}\text { Jean } & \text { n'a } & \text { pas } & \text { mangé. } \\ \text { Jean } & \text { NEG-AUX.3S } & \text { NEG } & \text { eat.PPL } \\ \text { 'Jean didn't eat.'/'Jean hasn't eaten.' } & \end{array}$

With preverbal pronouns, the ne preceeds the pronoun. If there is more than one pronoun (which occur in a string in a systematic order), ne preceeds them all. The inflected verb is immediately followed by pas.

F.4

Pierre ne me l'a $\quad$ pas dit.

Pierre NEG me it-AUX.3S NEG say.PPL

'Pierre didn't tell me that.'/'Pierre didn't say it to me.'

Before an infinitive, both particles are preverbal.

F.5

\begin{tabular}{|c|c|c|c|c|}
\hline $\begin{array}{l}\text { Il } \\
\text { EXP }\end{array}$ & $\begin{array}{l}\text { faut } \\
\text { be.necessary }\end{array}$ & $\begin{array}{l}\text { me } \\
\text { ISG.OBJ }\end{array}$ & $\begin{array}{l}\text { rappeler } \\
\text { remind.INF }\end{array}$ & $\begin{array}{l}\text { de } \\
\text { PART }\end{array}$ \\
\hline EG & $\begin{array}{l}\text { manger } \\
\text { eat.INF }\end{array}$ & $\begin{array}{l}\text { du } \\
\text { PART.AF }\end{array}$ & $\begin{array}{l}\text { fromage } \\
\text { cheese }\end{array}$ & $\begin{array}{l}\text { demain. } \\
\text { tomorrow }\end{array}$ \\
\hline
\end{tabular}

'It is necessary to remind me not to eat any cheese tomorrow.'

F.6

\begin{tabular}{|c|c|c|c|c|c|c|}
\hline $\begin{array}{l}\text { Ne pas } \\
\text { NEG NEG }\end{array}$ & $\begin{array}{l}\text { manger } \\
\text { eat.INF }\end{array}$ & $\begin{array}{l}\text { de } \\
\text { PART }\end{array}$ & $\begin{array}{l}\text { la } \\
\text { ART.F }\end{array}$ & $\begin{array}{l}\text { viande } \\
\text { meat }\end{array}$ & $\begin{array}{l}\text { le } \\
\text { ART.M }\end{array}$ & $\begin{array}{l}\text { vendredi } \\
\text { Friday, }\end{array}$ \\
\hline $\begin{array}{l}\text { c'est } \\
\text { EXPL-be.3S }\end{array}$ & $\begin{array}{l}\text { normal } \\
\text { normal }\end{array}$ & $\begin{array}{l}\text { pour } \\
\text { for }\end{array}$ & $\begin{array}{l}\text { les } \\
\text { the }\end{array}$ & $\begin{array}{l}\text { catholic } \\
\text { catholic }\end{array}$ & & \\
\hline
\end{tabular}

'Not eating meat on Fridays is normal for Catholics.' 
With imperatives, the basic structure of negation in MSF is the same as discussed above.

F.7

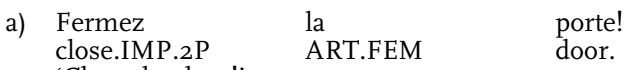

'Close the door!'

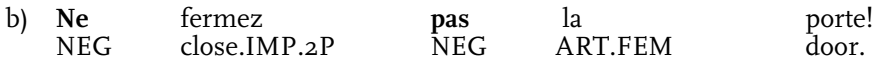

'Don't close the door!'

$\begin{array}{llll}\text { c) } & \text { la } & \text { fermez } & \text { pas! } \\ \text { NEG } & \text { PRO.FEM } & \text { close.IMP.2P } & \text { NEG }\end{array}$

d) Fermez-la!

close.IMP.2P-PRO.FEM

'Close it!'

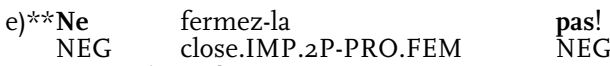

'Don't close it!'

$\begin{array}{ll}\text { f) } & \text { pas! } \\ \text { close.IMP.2P-PRO.FEM } & \text { NEG }\end{array}$

'Don't close it!'

MSF. $^{6}$

Both negative particles are required for grammatical negation in

F.8

$\begin{array}{clll}\text { a) } * * \text { Il } & \text { ne } & \text { mange } & \text { assez. } \\ \text { He } & \text { NEG } & \text { eats } & \text { enough. }\end{array}$

'He doesn't eat enough.'

b) ?Il mange pas assez.

$\mathrm{He}$ eats NEG enough

'He doesn't eat enough.'

F.9

$\begin{array}{lll}\text { ?Je } & \text { sais } & \text { pas. } \\ \text { IS } & \text { know.IS } & \text { NEG }\end{array}$

Some verbs, however, viz., savoir, pouvoir, oser, can be negated by ne alone with co-occurring infinitival complements.

$\begin{array}{cllll}\text { F.IO (Rowlett) } & & & & \\ \text { Pierre } & \text { ne } & \text { savait } & \text { que } & \text { faire. } \\ \text { Pierre } & \text { NEG } & \text { know.PST } & \text { what } & \text { do.INF }\end{array}$

'Pierre doesn't know what to do.'

${ }^{6} \mathrm{cf}$. Rowlett: \I.2.5, pp. $34 \mathrm{ff}$

${ }^{7}$ Nota bene: these sentences (F.8b and F.9) are grammatical in colloquial French and are standard in some dialects, e.g., Québécois. 
F.II

$\begin{array}{lll}\text { Je } & \text { n'osais } & \text { venir. } \\ \text { IS } & \text { NEG-dare.PST } & \text { come.INF }\end{array}$

'I don't dare come.' / 'I dare not come.'

F.I2

$\begin{array}{lllll}\text { On } & \text { ne } & \text { peut } & \text { vous } & \text { aider. } \\ \text { 3S } & \text { NEG } & \text { can.3S } & 2 \mathrm{P} & \text { help.INF } \\ \text { 'We can't help you.' } & & & \end{array}$

F.I3

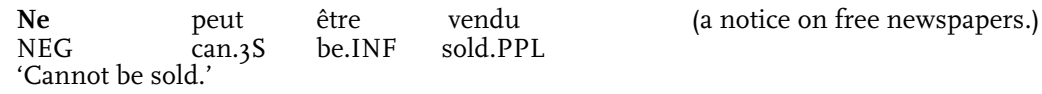

There are also some instances of pas standing alone in grammatical MSF.

F.I4

a) $\mathrm{Tu}$ viens ou pas?

$2 \mathrm{~S}$ come.3S or NEG

'Are you coming or not?'

$\begin{array}{lllll}\text { b) } * * \mathrm{Tu} & \text { viens } & \text { ou } & \text { ne } & \text { pas? } \\ 2 \mathrm{~S} & \text { come.3S } & \text { or } & \text { NEG } & \text { NEG }\end{array}$

'Are you coming or not?'

French also has other negative constructions, which are also formed with (at least) two co-occuring particles. In this paper, we are referring to these structures as "negative indefinites." With negative indefinites, we see the same pattern as with ne $\mathrm{V}$ pas.

$\begin{array}{llll}\text { ne V jamais } & \text { 'never' } & \text { ne V plus } & \text { 'no more' } \\ \text { ne V personne } & \text { 'nobody'/'no one' } & \text { ne V point } & \text { 'none' } \\ \text { ne V nulle part } & \text { 'nowhere' } & \text { ne V rien } & \text { 'nothing' } \\ \text { ne V aucun } & \text { 'none' } & \text { ne V pas encore } & \text { '(not) yet' }\end{array}$

F.I5

$\begin{array}{llll}\text { Jean } & \text { ne } & \text { nage } & \text { jamais } \\ \text { Jean } & \text { NEG } & \text { swims } & \text { never.NI } \\ \text { 'Jean never swims.' } & & \end{array}$

F.I6

$\begin{array}{llll}\text { Jean } & \text { ne } & \text { voit } & \text { personne. } \\ \text { Jean } & \text { NEG } & \text { sees } & \text { nobody.NI }\end{array}$

'Jean sees no one/nobody.'/'Jean doesn't see anyone/anybody.'/Jean isn't seeing anyone/anybody.

F.I7

$\begin{array}{lccc}\text { Jean } & \text { ne } & \text { voyage } & \text { nulle part. } \\ \text { Jean } & \text { NEG } & \text { travel.3S } & \text { nowhere.NI } \\ \text { 'Jean travels nowhere.'/Jean doesn't travel anywhere.' }\end{array}$

Certain NIs can be fronted and act as subjects, e.g., personne, rien, aucun; but, they must occur with the pre-verbal negative particle, $n e$.

F.I8

Personne ne voit Jean.

nobody.NI NEG see.3S John

'No one/Nobody sees John.' 
F.I9

Aucun mes élèves ne font leurs devoirs. none.NI PART my student.P NEG do.3P their homework 'None of my students do their homework.'

With imperatives, the basic structure of negation in MSF is the same as discussed above, i.e, ne $\mathrm{V}$ pas.

F.20

Fermez la porte!

close.IMP.2P ART.FEM door

'Close the door!'

F.2I

$\begin{array}{lllll}\text { Ne } & \text { fermez } & \text { pas } & \text { la } & \text { porte! } \\ \text { NEG } & \text { close.IMP.2P } & \text { NEG } & \text { ART.FEM } & \text { door. }\end{array}$

'Don't close the door!'

F.22

$\begin{array}{llll}\mathrm{Ne} & \text { la } & \text { fermez } & \text { pas! } \\ \text { NEG } & \text { PRO.FEM } & \text { close.IMP.2P } & \text { NEG }\end{array}$

'Don't close it!'

F.23

Fermez-la!

close.IMP.2P-PRO.FEM

'Close it!'

F.24**

$\mathrm{Ne}$ fermez-la pas

NEG close.IMP.2P-PRO.FEM NEG

'Don't close it!'

F.25

?Fermez-la pas!

close.IMP.2P-PRO.FEM NEG

'Don't close it!'

Inversion

In French, a common strategy for forming yes/no questions is by using inversion.

F.26

Tu vas au théâtre.

'You are going to the theater.'

F.27

Vas-tu au théâtre?

'Are you going to the theater?'

In negative yes/no questions, ne...pas circumscribes the inverted verb-subject pronoun construction: $n e$ V-PRO pas, as seen in (F.28).

F.28

Ne vas-tu pas au théâtre?

NEG go.2S-2S.Q NEG to.the theater

'Aren't you going to the theater?' 
An interesting feature of the negative particle, ne, in French: Pleonastic ne.

In MSF, there is an aspect of the negative particle, ne, which leads us to question whether it is actually inherently negative. In MSF, ne can be used pleonastically in sentences that are not semantically negative. For example, this expletive usage of $n e$ is found with some constructions employing the subjunctive (F.29). Pleonastic ne is also very common in (formal) comparative constructions (F.3O) \& (F.3I).

F.29

$\begin{array}{lllll}\text { Je } & \text { dois } & \text { finir } & \text { mes } & \text { devoirs } \\ \text { IS } & \text { must.IS } & \text { finish.INF } & \text { my.PL } & \text { homework }\end{array}$

avant que Maman ne rentre.

before Mom NEG.EXPL return.3S.SUBJ

'I must finish my homework before Mom returns.'

F.30 (Price 1990)

Pierre est plus riche que son père ne l'était.

Pierre be.3S COMP rich than his father NEG.EXPL (PRO.rich)-was

'Pierre is richer than his father was.'

F.3I

Ce travail est plus difficile que l'on ne le croyait. DEM work be.3S more difficult REL EXPL.3S NEG.EXPL PRO thought.

'This work is harder than we thought.'

\section{HOW THEY DON'T NOT COMPLY}

In this section we will discuss a variety of Romance Languages and whether they are in accordance with Zanuttini's generalizations. The following charts show how these languages fit into Groups I, 2, or 3, which were previously introduced. Whenever we refer to these languages regarding their negation strategies, we presuppose their membership in one of the groups below.

Group r: Pre-verbal negation only

\begin{tabular}{|l|l|}
\hline Language & Example \\
\hline Spanish & $\begin{array}{l}\text { Juan no ha llamado a su madre. } \\
\text { 'Juan NEG AUX call.PPL PREP his mother } \\
\text { 'Juan did not call his mother.' }\end{array}$ \\
\hline Catalan & $\begin{array}{l}\text { En Joan no va entendre tot } \\
\text { ART Joan NEG AUX understand everything } \\
\text { 'Joan didn't understand everything.' }\end{array}$ \\
\hline Italian & $\begin{array}{l}\text { Lui non legge } \\
\text { He NEG read.PRES.3S } \\
\text { 'He does not read well.' }\end{array}$ \\
\hline
\end{tabular}




\begin{tabular}{|l|l|}
\hline Sicilian & $\begin{array}{l}\text { Unn u } \\
\text { NEG him capisciu } \\
\text { 'I don't understand him.' }\end{array}$ \\
\hline Venetian & $\begin{array}{l}\text { No ti } \\
\text { NEG SUB.CL }\end{array}$ \\
'You do not come.'
\end{tabular}

Group 2: Post-verbal negation only

\begin{tabular}{|c|c|}
\hline Language & Example \\
\hline Milanese & $\begin{array}{llll}\text { L'a } & \text { minga } & \text { semper } & \text { vinciü } \\
\text { SUB.CL-AUX.3S } & \text { NEG } & \text { always } & \text { win.PPL } \\
\text { 'He didn't always win.' } & & \end{array}$ \\
\hline Occitan & $\begin{array}{lll}\text { Vôl } & \text { pas } & \text { venir. } \\
\text { wants.3S } & \text { NEG come.INF } \\
\text { 'He doesn't want to come.' }\end{array}$ \\
\hline Piedmontese & 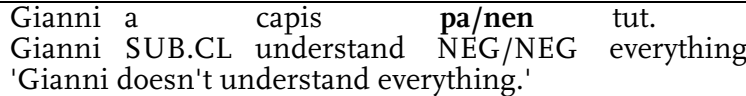 \\
\hline Québécois & $\begin{array}{lll}\text { Il parle pas } & \text { jamais. } \\
\text { 3S } & \text { speak.3S NEG } & \text { never.NI } \\
\text { 'He never speaks.' } & \end{array}$ \\
\hline Waldensian Patouà & 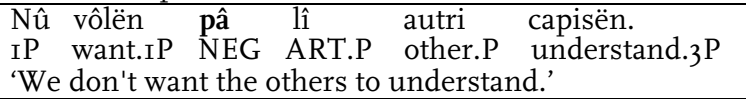 \\
\hline
\end{tabular}

Group 3: Co-occurance of pre- and post-verbal negation

\begin{tabular}{|c|c|}
\hline Language & Example \\
\hline French & $\begin{array}{lllll}\text { Il } & \text { ne } & \text { mange } & \text { pas } & \text { assez. } \\
\text { 3S.M } & \text { NEG } & \text { eat.3S } & \text { NEG } & \text { enough } \\
\text { 'He doesn't eat enough.' } & & \end{array}$ \\
\hline Wallon & $\begin{array}{llll}\text { N'èsteût-ç' } & \text { nin } & \text { avou } & \text { d' l'angrês ? } \\
\text { NEG-bs.PST.3S-ART.EXPL } & \text { NEG } & \text { with } & \text { PART ART- } \\
\text { fertilizer } & & & \\
\text { 'Wasn't it with fertilizer?' } & & & \end{array}$ \\
\hline *Catalan & 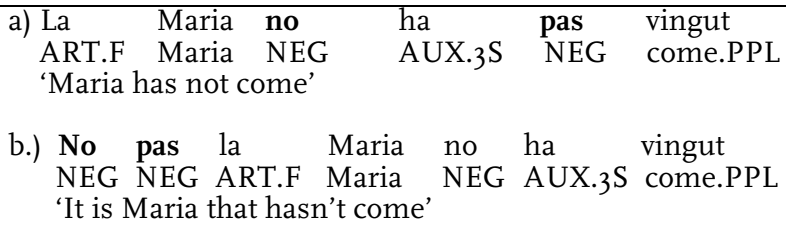 \\
\hline
\end{tabular}

* Catalan can utilize the negative morpheme pas in both pre-verbal and post-verbal position. The presence of pas has several functions, including for emphatic purposes as well as to express an occurrence contrary to the expectations of the speaker. Unlike in French and Occitan, pas is not an independent lexical unit, but is lexically and syntactically inseparable from no. (Espinal, I991; 39) 
I. Negative markers in relation to pronominal clitics in pre-verbal position

Again, Zanuttini (I997b: 2I7) claims that "the pre-verbal negative markers which can negate a clause alone, for example Italian non, Spanish no, and Portuguese não, always occur to the left of a string of pronominal clitics in pre-verbal position."

Standard Spanish functions accordingly, with no preceding the first person pronominal clitic $m i$ in (Sp.ra). In (Sp.Ib), the pronominal dative clitic se and the direct object clitic lo both follow the sentential negator no.

Sp.I

a) Juan no me ha visto
Juan NEG me
AUX.3S
see.PPL
b) Maria no $\quad$ se
Maria NEG in PRO.DAT
'Maria didn't give it to him.'
lo dió
it give.PST.3S

This is consistent in Standard Italian. In the example (It.Ia) below, non precedes the pronominal clitic mi, and the combined direct and indirect clitic gliel-.

It.I

a) John non $\mathrm{mi}$ ha visto John NEG me AUX.3S see.PPL

b) Maria non gliel'ha dato Maria NEG him-it-AUX.3S give.PPL

'Maria didn't give it to him.'

Catalan follows suit, where no precedes the pronominal clitic $m^{\prime}$ in (C.ra). In (C.Ib), the no again precedes the pronominal indirect object clitic $l^{\prime}$ as well as the direct object clitic hi.

Ca.I

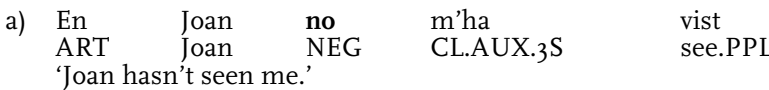

$\begin{array}{llllll}\text { b) La } & \text { Maria no } & \text { l'hi } & \text { va } & \text { donar } \\ \text { ART } & \text { Maria } & \text { NEG } & \text { PRO.it } & \text { AUX.3S } & \text { give.INF }\end{array}$

'Maria didn't give it to him.'

This appears to hold true in Sicilian as well. The negative marker unn must come before any pronominal clitics that precede the verb.

Si.I(Privitera 1998)

$\begin{array}{lll}\text { Unn } & \mathrm{u} & \text { capisciu } \\ \text { NEG } & \text { him.CL } & \text { understand.PRES.IS }\end{array}$

'I don't understand him'

The negative marker no in Venetian must also come before pronominal clitics preceding the verb. 
Ve.I (Poletto 2000)
a) $\mathrm{La}$ mangia
SUB.CL eat.PRES.3S
'She eats.'
b) No $\quad$ ti $\quad$ SEG $\quad$ SUB.CL
'You do not come.'
vien come.PRES.3S
$\begin{array}{ll}\text { c) } & \text { la } \\ \text { NEG SUB.CL } & \text { SUB does not come.' }\end{array}$
vien
come.PRES.3S

Zanuttini suggests, however, that Group 3 languages' pre-verbal negative markers "do not systematically precede a string of pronominal clitics in preverbal position." She gives as evidence of this some data from the Piemontese dialect, Cairese (cf. X.8 and X.9). French gives evidence, however, that counters her statement. French does seem to systematically place its pre-verbal negative marker, ne, before a string of preverbal pronominal clitics.

Fr.I

$\begin{array}{llllll}\text { Pierre } & \text { ne } & m e & \text { l'a } & \text { pas } & \text { dit. } \\ \text { Pierre } & \text { NEG } & \text { me } & \text { it-AUX.3S } & \text { NEG } & \text { say.PPL }\end{array}$

'Pierre didn't tell me that.'/'Pierre didn't say it to me.'

Fr.2

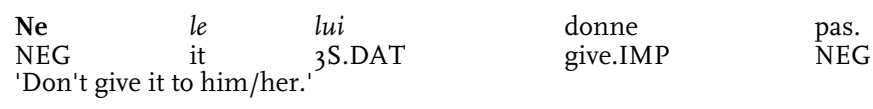

Fr.3

Pourquoi n'en $\quad$ prenez-vous pas?

Why aren't you taking any?

Zanuttini has not made a very strong (or convincingly correct) typological statement here. Perhaps Group 3 as a whole does not systematically place pre-verbal negative particles before clitics; but there are certainly languages in Group 3 that do, as seen in French above.

\section{Negative imperatives}

Again, according to Zanuttini (1997b: 218), the negative marker in Group I languages "cannot occur in imperative clauses which employ a verbal form unique to the imperative paradigm."

Standard Spanish adheres to Zanuttini's second generalization. The positive imperative forms of the second person singular (Sp.za and Sp.2d) are not the same as their negative counterparts (Sp.2b and Sp.2e). (Sp.2c) and (Sp.2f) show the ungrammaticality of sentences formed in this way. When forming the negative command, the subjunctive form of the verb is used instead of the inflected form for present tense. This contrasts with the verb inflected for third person singular present that is utilized for the second person singular command 
Sp.2

a) ¡Come!

Eat.IMP.2S

'Eat!'

b) ¡No comas!

NEG eat.IMP.SUBJ.2S

'Don't eat!'

c) $* *$ jo Nome!

NEG eat.IMP.2S

'Don't eat!'

d) ¡Habla!

talk.IMP.2S

'Talk!'

e) ¡No hables!

NEG speak.IMP.SUBJ.2S

'Don't talk!

f) $* *$;No habla!

NEG talk.IMP.2S

'Don't talk!'

Standard Italian adheres to Zanuttini's second generalization. The positive imperative forms of the second person singular (It.2a and It.2d) are not the same as their negative counterparts (It.2b and It.2e). When forming the negative command, the infinitive of the verb is used instead of the inflected form.

It.2

a) Mangia!

Eat.IMP.2S!

'Eat!'

b) Non mangiare!

NEG eat.IMP.INF.2S

'Don't eat!'

c)**Non mangia!

NEG eat.IMP.2S

'Don't eat!'

d) Parla!

Talk.IMP.2S

'Talk!'

e) Non parlare!

NEG talk.IMP.INF.2S

'Don't talk!'

f) ** Non parla!

NEG talk.IMP.2S

'Don't talk!'

Standard Catalan likewise functions according to Zanuttini's claim and parallels Spanish in its use of the subjunctive for the negative imperative in second person singular informal.

Ca.2

a) Menja!

eat.IMP.2S

'Eat!' 
NEG eat.IMP.SUBJ.2S
'Don't eat!'

c) $* *$ No menja!

NEG eat.IMP.2S

'Don't eat!'

d) Parla!

talk.IMP.2S

'Talk!'

e) No parlis!

NEG talk.IMP.SUBJ.2S

'Don't speak'

f) $* *$ No parla!

NEG talk.IMP.2S

'Don't speak!'

Accordingly, negative second person imperatives in Sicilian utilize a different verb form than the positive form.

Si.2 (Privitera I998)

a) Fallu

Do.IMP.2S

Do it!

b) Unn $u \quad$ fari

NEG it do.IMP.INF.2S

'Don't do it!'

Group 3 languages, contrastingly, do not show the same differences between the positive and negative second person singular imperatives (cf., X.II).

In French, in accordance with Zanuttini's description, the imperative paradigm does not change in the negative vis-à-vis the positive.

Fr.4

Fermez la porte!

close.IMP.2P ART.FEM door.

'Close the door!'

Fr.5

$\begin{array}{lllll}\mathrm{Ne} & \text { fermez } & \text { pas } & \text { la } & \text { porte! } \\ \text { NEG } & \text { close.IMP.2P } & \text { NEG } & \text { ART.FEM } & \text { door. }\end{array}$

'Don't close the doc

Fr.6

$\begin{array}{llll}\text { Ne } & \text { la } & \text { fermez } & \text { pas! } \\ \text { NEG } & \text { PRO.FEM } & \text { close.IMP.2P } & \text { NEG }\end{array}$

'Don't close it!'

Unrelated to the verbal paradigm - yet extremely interesting there is, however, a constraint on inversion in the negation strategy when clitics are present in imperatives, as seen below in (Fr.7). The only way to grammatically produce the negative counterpart to (Fr.7a) is (Fr.6). 
a) Fermez-la!

close.IMP.2P-PRO.FEM

'Close it!'

$\begin{array}{ccc}\text { b) } * * \text { Ne } & \text { fermez-la } & \text { pas! } \\ \text { NEG } & \text { close.IMP.2P-PRO.FEM } & \text { NEG }\end{array}$

'Don't close it!'

c) ?Fermez-la close.IMP.2P-PRO.FEM

'Don't close it!'

pas!

(colloq.)

\section{Negative Indefinites}

In Group I languages, "negative indefinites in post-verbal position must co-occur with a negative element in pre-verbal position" (I997b: 2I9).

Accordingly, Spanish negation typically requires the sentential negator no before the appearance of a negative indefininte. The second example in (Sp.3b) is rendered ungrammatical in that a negator must appear before the inflected verb 'to see' in order for the negative indefinite nadie to appear. When the NI precedes the verb in (Sp.3C), however, no additional negator is required for the sentence to be grammatical.

Sp.3

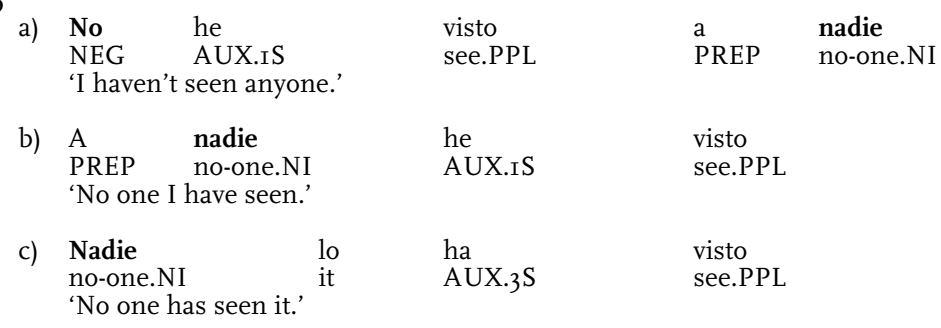

Zanuttini fails, however, to address any instances in which a negative indefinite can occur in post-verbal position without the presence of no in preverbal position. Post-verbal negative indefinites can appear in the complements of negative prepositions, negative embedding predicates and adversative predicates, certain emotive predicates, and comparativelike contexts (Herburger, 297) (S.6a-b) provide additional examples similar to those seen earlier in (S.7a-c) The supposed inherently negative nature of the indefinite is put into question, as no negative meaning is extracted from the indefinite in translation.

Sp.3

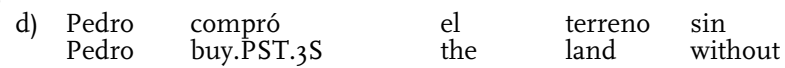

$\begin{array}{lll}\text { contarselo } & \text { a } & \text { nadie } \\ \text { tell.INF.CL.it } & \text { PREP } & \text { no-one.NI }\end{array}$

'Pedro bought the land without telling anybody'
e) Dudo
Doubt.PRES.IS que 'I doubt he will find anyone'
vayan go.SUBJ.3P to
encontrar nadie find.INF no-one.NI 
In Spanish, negative indefinite adverbs cannot occur between an auxiliary verb and its complement. A sentential negator is not necessary, though the negative indefinite adverb must appear pre-verbally. It is interesting to note that the subsequent negative indefinite in the examples (Sp.3f-g) is interchangeable with a positive indefinite.

Sp.3

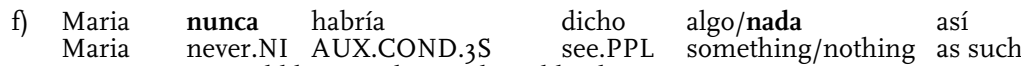
'Maria never would have said something like that.'

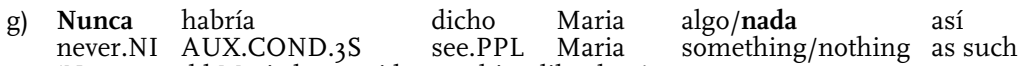
'Never would Maria have said something like that.'

Standard Italian complies with Zanutini's description as well. When the negative indefinite, such as nessuno follows the verb, non must precede it. However, when the NI precedes the verb, non is not needed. It should be noted, however, that sentences like (It.3b) are not very common, and the object of the verb is usually only inverted to add emphasis. Sentences such as (It.3c), where the NI is acting as a subject are much more acceptable.

It.3
a) Non ho visto nessuno.
NEG AUX.IS see.PPL no-one.NI
'I have seen no one.'
b) Nessuno, ho visto.
No-one.NI AUX.IS see.PPL
'No one I have seen.'
c) Nessuno l'ha visto.
'No one saw it'
no-one.NI it.CL-AUX.3S see.PPL

Negative indefinite adverbs often occur between an auxiliary verb and its complement, as in (It.4a) where mai comes between the auxiliary avrebbe and the complement detto. When it follows the auxiliary, however, it is important that non is in pre-verbal position. Again, when the NI precedes the verb, non is not needed. Unlike (It.3b) above, where the NI acted as an object, the NI mai, which acts as an adverb, can frequently occur in preverbal position.

It.3

\begin{tabular}{|c|c|c|c|c|c|}
\hline $\begin{array}{l}\text { Maria } \\
\text { Maria }\end{array}$ & $\begin{array}{l}\text { non } \\
\text { NEG }\end{array}$ & $\begin{array}{l}\text { avrebbe } \\
\text { AUX.COND.3S }\end{array}$ & $\begin{array}{l}\text { mai } \\
\text { never.NI }\end{array}$ & $\begin{array}{l}\text { detto } \\
\text { say.PPL }\end{array}$ & $\begin{array}{l}\text { una } \\
\text { a }\end{array}$ \\
\hline $\begin{array}{l}\text { del } \\
\text { of-the }\end{array}$ & $\begin{array}{l}\text { genere } \\
\text { Sort }\end{array}$ & & & & \\
\hline
\end{tabular}

'Maria would have never said anything like that.'

e) Mai Maria non avrebbe detto una cosa never.NI Maria NEG AUX.COND.3S say.PPL a thing

del genere.

'Never would Maria have said anything like that.' 
Standard Catalan functions accordingly, and a negative indefinite in post-verbal position typically cannot appear without a pre-verbal no. Postverbally this is not the case, as the negative indefinite can appear without the presence of a prior no. An expletive negator no can appear after the indefinite, but it is purely optional.

Ca.3

\begin{tabular}{|c|c|c|c|c|c|c|}
\hline a) & $\begin{array}{l}\text { No } \\
\text { NEG }\end{array}$ & $\begin{array}{l}\text { he } \\
\text { have.IS }\end{array}$ & $\begin{array}{l}\text { vist } \\
\text { see.PPL }\end{array}$ & $\begin{array}{l}\text { ningi } \\
\text { no-or }\end{array}$ & & \\
\hline b) & $\begin{array}{l}\text { A } \\
\text { PREP }\end{array}$ & $\begin{array}{l}\text { ningú } \\
\text { no-one.NI }\end{array}$ & & $\begin{array}{l}\text { (no) } \\
\text { NEG }\end{array}$ & $\begin{array}{l}\text { he } \\
\text { have.IS }\end{array}$ & see.PPL \\
\hline & $\begin{array}{l}\text { Ningú } \\
\text { no-one.NI }\end{array}$ & & $\begin{array}{l}\text { (no) } \\
\text { NEG }\end{array}$ & $\begin{array}{l}\text { m'ha } \\
\text { me.A }\end{array}$ & & $\begin{array}{l}\text { vist } \\
\text { see.PPL }\end{array}$ \\
\hline
\end{tabular}

'I haven't seen anyone.'

Additionally, like in Spanish, negative indefinites can be licensed in post-verbal negative indefinites, in the complements of negative prepositions, negative embedding predicates and adversative predicates, certain emotive predicates, and comparative-like contexts. See the example (Ca.3d).

Ca.3 (Espinal, 2000a:54)

$\begin{array}{lllll}\text { d) Abans que } & \text { passi } & \text { res, } & \text { jo } & \text { me } \\ \text { Before that } & \text { happen.SUBJ.3S } & \begin{array}{l}\text { nothing } \\ \text { IS }\end{array} & \text { CL } \\ \text { n'aniria } & & & & \\ \text { CL.go.COND.IS } & & & \end{array}$

'Before anything happens, I would go.'

In the Roussillon dialect of Catalan, spoken in Northern Catalonia and in Southwestern France, negative indefinites do not require the presence of a pre-verbal no, rendering (RC.a-c) grammatical.

RC. (Espinal, 200ob:565)
a) Jo he vist ningú
IS have.IS seen no one
'I have seen no one'

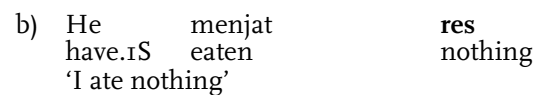

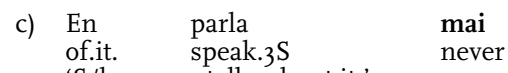
'S/he never talks about it.'

In (RC.a-c), unlike the example in (Ca.3d), the negative indefinites retain a fully negative value and cannot be interpreted as 'someone', 'something', and 'ever', respectively. This departs from Zannutini's claim that negative indefinites are universal quantifiers. To the contrary, it might be best to describe negative indefinites as indefinites having a variable quantificational nature (Matos, 563).

Sicilian also complies with this generalization. When a negative indefinite appears after the verb, the pre-verbal negative marker unn is 
necessary (Si.za). On the other hand, when the negative indefinite precedes the verb, unn is not needed (Si.3b)

Si.3 (Privitera: 34) $\begin{array}{llll}\text { a) Unn haiu vistu } & \text { nessunu } \\ \text { NEG AUX.IS } & \text { see.PPL } & \text { no-one.NI } \\ \text { 'I have seen nobody' } & & \end{array}$

b) Nessun populu u pussedi no-one.NI people it possess

'No people possesses it'

No overt evidence was found regarding a compulsory pre-verbal negative marker in the presence of a post-verbal negative in Venetian. However, the negative imperative can stand alone when it is preverbal. Since Venetian seems to be following many of the Zanuttini's trends for Group I, I would posit that a post-verbal negative indefinite requires a preverbal negative marker as well.

Ve.3 (Poletto:I4I)

$\begin{array}{ll}\text { Nisun } & \text { magna } \\ \text { Nobody.NI } & \text { eat.PRES.3S } \\ & \text { Nobody eats' (P:I4I) }\end{array}$

Zanuttini generalizes that languages in Group 3 do not adhere to the same constraints. "In these languages, it is possible to find [negative indefinites] in post-verbal position in the absence of a negative element cooccuring in pre-verbal position" (Zanuttini I997b: 220). French does support this statement in that it is possible to find negative indefinites in such a position-however only in informal/colloquial language. Otherwise, in MSF, the pre-verbal negative particle is required.

Fr.8

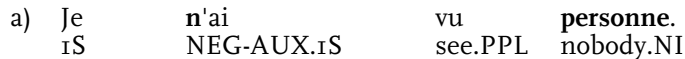

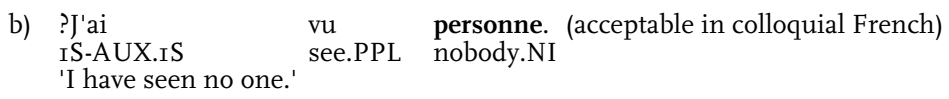

As seen in (Fr.9), negative indefinites do not even seem possible in preverbal positions.

Fr.9

\begin{tabular}{|c|c|c|c|}
\hline $\begin{array}{c}\text { a) } * * \text { Personne } \\
\text { nobody.NI }\end{array}$ & \multicolumn{2}{|c|}{$\begin{array}{l}\text { n'ai-je } \\
\text { NEG-AUX.IS-IS }\end{array}$} & $\begin{array}{l}\text { vu. } \\
\text { see.PPL }\end{array}$ \\
\hline $\begin{array}{c}\text { b) } * * \text { Personne } \\
\text { nobody.NI }\end{array}$ & $\begin{array}{l}\text { je } \\
\text { IS }\end{array}$ & $\begin{array}{l}\text { n'ai } \\
\text { NEG-AUX.IS }\end{array}$ & $\begin{array}{l}\text { vu. } \\
\text { see.PPL }\end{array}$ \\
\hline $\begin{array}{c}\text { c) } * * \text { Personne } \\
\text { nobody.NI }\end{array}$ & $\begin{array}{l}\text { j'ai } \\
\text { IS }\end{array}$ & $\begin{array}{l}\text { vu. } \\
\text { see.PPL }\end{array}$ & \\
\hline
\end{tabular}

'No one I have seen.' (= (Fr.8a,b) but with emphasis on no one in English)

However, (Fr.Io) does show a grammatical instance of NI fronting with jamais. In both sentences below, ne is required in MSF despite the NI's position relative to the verb. 
Fr.IO

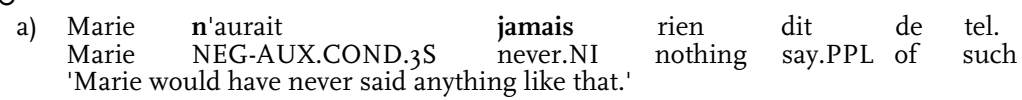

b) Jamais Marie n'aurait rien dit de tel. Never.NI Marie NEG-AUX.COND.3S nothing say.PPL of such 'Never would Marie have said anything like that.'

It seems difficult to make a strong typological statement about this construction for Group 3 languages (except that these languages do not impose the same constraint as found in Group I) since, on the surface level in these languages, NIs in post-verbal position appear in varying positions and with varying co-occurrence of pre-verbal negative particles with different degrees of acceptability.

\section{Yes/No questions}

Again in Group I languages, "A question is formed by maintaining the same word-order found in non-interrogative clauses, where the negative marker precedes the subject clitic, which in turn precedes the finite verb" (Zanuttini I997b: 22I).

It is more difficult to prove Zanuttini's final generalization in Standard Spanish as it is a pro-drop language and does not utilize mandatory subject clitics. Therefore the pronoun is optional in the following sentences, and no subject clitic is necessary. The only exception to this lies in certain reflexive clitics that obligatorily appear immediately preceding certain verbs. If the pronoun isn't dropped, it can appear on either side of the verb in positive or negative questions. The sentential negator no, however, must always appear pre-verbally.

Sp.4

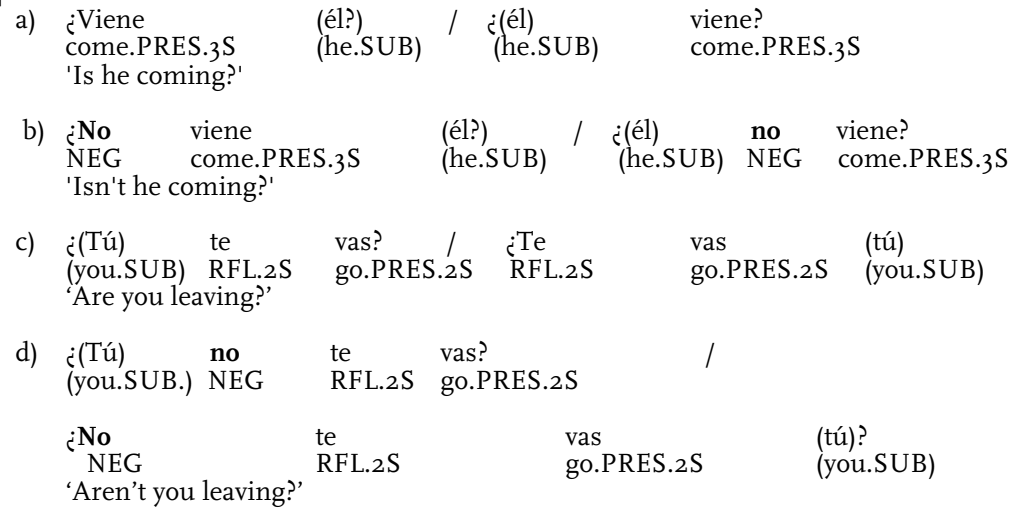

Standard Italian functions similarly to Spanish in that it is a prodrop language and does not require the presence of subject clitics. The pronouns appearing in the following sentences are optional and can appear on either side of the verb in positive and negative questions. If the pronoun is not dropped and is placed before the verb, it also comes before the negative marker non (It.4b and It.4d). It is clear, however, that, when used, the negative marker non must always precede the verb and is never inverted. 
It.4
a) Viene
(lui)?
(he.SUB) /
(Lui)
viene?
Come.PRES.3S
(he.SUB
come.PRES.3S

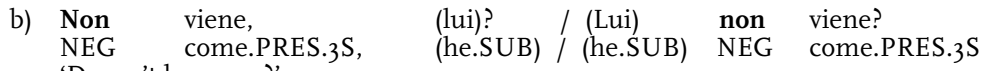
'Doesn't he come?'
c) Parti, $\quad(\mathrm{tu})$ ? $/ \quad(\mathrm{tu}) \quad$ parti? Leave.PRES.2S (you.SUB) / (you.SUB) leave.PRES.2S
'Are you leaving?'
d) Non parti, (tu)? / (tu) non parti? NEG leave.PRES.2S, (you.SUB) / (you.SUB) NEG leave.PRES.2S 'Aren't you leaving?'

We might not see the trends Zanuttini suggests due to Standard Italian's lack of subject clitics. Her argument becomes weaker since she does not explicitly define some of the prerequisites that make her claim valid.

Ca.4
a) $\mathrm{Ve}$ (ell)? (he.SUB) /
('Ell) (he.SUB)
ve?
Come.PRES.3S
$/$
Come.PRES.3S
b) No ve
NEG come.PRES.3S
'Isn't he coming?'

$\begin{array}{llll}\text { (ell)? } & \text { / (Ell) } & \text { no } & \text { ve? } \\ \text { (he.SUB) } / \text { (he.SUB) } & \text { NEG } & \text { come.PRES.3S }\end{array}$

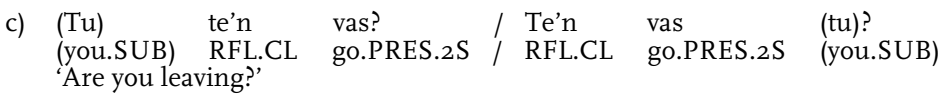

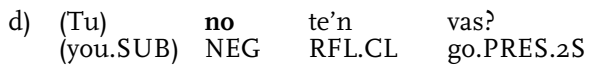

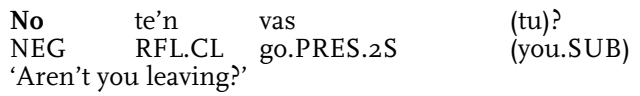

Although no explicit examples of negative yes/no questions could be found for Sicilian, it appears to exhibit similar characteristics to Italian interrogatives. Sicilian appears to be a pro-drop language, since the person and number are reflected in the verb inflection, therefore no subject markers of any kind are necessary in either positive or negative questions. In negative question formation, it seems that the negative marker must still precede the verb.

Si.4 (Privitera: 38-4I)
a) $\mathrm{Ha}$ parratu di so patri? AUX.3S speak.PPL, of his father 'Has he spoken of this father?'
b) Pirchì unn rispunni? Why NEG respond.PRES.2S 'Why don't you respond?'


Languages in Group 3, on the other hand, "show inversion of the verb around the pronominal subject" (Zanittini I997b: 222). French is in accordance with Zanuttini's description above as seen in (X.I4) and in the examples below.

Fr.II

a) Vient-il?

come.3S-he.Q

'Is he coming?'

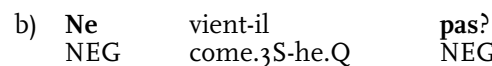

'Isn't he come?'

Fr.I2

a) Pars-tu?

leave.2S-2S.Q

'Are you leaving?'

$\begin{array}{lll}\mathrm{Ne} & \text { pars-tu } & \text { pas? } \\ \mathrm{NEG} & \text { leave.2S-2S.Q } & \text { NEG }\end{array}$

'Aren't you leaving?'

below.

Wallon also supports her supposition as seen in the example

Wa.I

N'è-ç nin come dès cantikes ou cwè?

NEG-is-it.EXPL NEG like PART odes or what?

'Isn't it like odes, or what?'

\section{Discussion of Group 2 LANGUAGES}

Jespersen's Cycle

The three groups we mention in this paper can be analyzed as having come from a diachronic change that Linguists often refer to as Jespersen's cycle-each group giving us a synchronic example of Languages at different stages in the cycle. We know that the Romance languages have Late Latin (sermo vulgaris) as their common root. So, why is it that there is disparity among the ways in which they form negatives? Jespersen's cycle gives us an historical perspective on these phenomena. Jespersen generalizes that many languages initially have one negative marker, which for one reason or another (often thought to be phonetic) weakens and is then bolstered by a second marker (often an adverb or NP). Eventually, the original marker becomes even weaker, rendering it optional. Finally the original marker is deleted altogether leaving the "new" particle to be the sole marker of negation in the language. From here, the cycle may start again. Jespersen (I924/1992) gives us examples citing Latin and one of its "offspring" languages, French. Latin ne became too weak and was then strengthened by oenum. This construction, ne-oenum, gave rise to Latin non, which subsequently (over centuries, of course) lost its stress and became French ne. French ne was the only negative marker for a while until it was thought to be too weak and was strengthened by pas (Zanuttini i997a: I2). 
This is the current state of Standard Modern French; however, in spoken French, ne is optional and is often deleted, while in colloquial French and certain dialects, e.g., Québécois, ne has been deleted altogether. J.I ${ }^{8}$
a) Jeo ne di.
(up to 1600 )
b) Jeo ne dis (pas).
(I600 - I700)
c) Je ne dis pas.
(Standard written French)
d) Je (ne) dis pas.
(Standard spoken French)
e) Je dis pas.
(Colloquial French \& some dialects)

Recalling the groups of languages we outlined earlier, we can associate each group with a stage in Jespersen's cycle. Group I has preverbal negative particles. Group 3 languages are in the stage where preverbal and post-verbal markers co-occur; and, Group 2 languages have lost their pre-verbal marker leaving only the post-verbal one.

Many of the Northern dialects of Italy, such as Piedmontese, use only a post-verbal negative marker, instead of the pre-verbal or a cooccurance of the two. Zanuttini cites several examples in her article (Zanuttini 1997), exemplifying various word-orderings of Piedmontese. There are two different negative markers in this language variety: $p a$ and nen. Nen functions as the regular negation marker, while $p a$ conveys some type of presuppositional knowledge. It appears that both always appear after the verb (J.2a). When there is an auxiliary verb, the negative marker comes between the auxiliary and its complement (J.2b).

J.2 (Zanuttini I997b)

a) Gianni a

capis pa / nen

Gianni SUB.CL understand NEG / NEG

'Gianni doesn't understand everything.'

b) Gianni a l'ha pa / nen

Gianni SUB.CL CL-AUX.3S NEG/ NEG

'Gianni didn't understand everything.' tut.

everything

capì tut.

understand.PPL everything

Interestingly, when forming a negative imperative, both negative markers can be used but only in one order: $p a+n e n$. Again, the negative marker is found after the verb.

J.3 (Zanuttini I997b)
a) $\underset{\text { do.IMP.2S }}{\mathrm{Fa}}$
'Don't do that!'
$\begin{array}{lll}\text { pa } & \text { nen } & \text { sulì } \\ \text { NEG } & \text { NEG } & \text { that }\end{array}$

Milanese, spoken around Milan in Northern Italy, also exhibits similar tendency towards post-verbal negation. In the example below, the negative marker minga comes after the finite verb.

\footnotetext{
${ }^{8}$ from Jespersen I924/I992, pp 335-6 as quoted in Rowlett pp89-93
} 
J.4 (Zanuttini I997b)

$\begin{array}{llll}\text { a) L'a } & \text { minga } & \text { semper } & \text { vinciü } \\ \text { SUB.CL-AUX.3S } & \text { NEG } & \text { always } & \text { win.PPL }\end{array}$

'He didn't always win'

It is interesting to note, however, that when using the negative marker no, it must come after the final verb. This means that in cases with the auxiliary + complement, the negative marker no comes after the complement.

J.5 (Zanuttini I997b)
a) El l'ha
SUB.CL CL-AUX.3S
'He hasn't written.'
scrivuu
write.PPL
no
b) $* *$ El l'ha no scrivuu
SUB.CL CL-AUX.3S NEG write.PPL

'He hasn't written.'

In the dialect of Occitan spoken by the Valdese [val.'de.ze] in the valleys of the Italian Alps-as well as in Valdese ['væl.diz], North Carolinasentential negation is formed by inserting the particle $p \hat{a}$ after the verb-or in the case of compound tenses, following the AUX.

$\begin{array}{lll}\text { Pa.I (Pons, C.) } & & \\ \text { Vöi } & \text { pâa } & \text { anar. } \\ \text { want.IS NEG } & \text { go.INF } \\ \text { 'I don't want to go.' } & \end{array}$

Pa.2

E d'autrâ ocaziun parlu pâ Patouà, s'no chë nû vôlën

And PART.other occasion.P speak.IS NEG Patouà, unless IP want.IP

dire düi mus chë nû vôlën pâ lî autri capisën.

say.INF two word REL IP want.IP NEG ART.P other.P understand.3P

'And on other occasions, I don't speak Patouà, unless we want to say something that we don't want the others to understand.'

verb.

However, the negative article precedes infinitival forms of the

Pa.3

Ai dësidrà dë pâ partir.

AUX decided.PPL PREP NEG leave.INF

'I (have) decided not to go.'

Negative Indefinites

The same structure is true with negative indefinites in this dialect (hereafter referred to as Waldensian Patouà or, simply, Patouà) i.e., the negative particle follows the verb.

zamé

Pa.4 (Pons, T.)

Â sorto zamé.

${ }_{3} \mathrm{~S}$ goes.3 $\mathrm{S}$ never.NI

'He never goes there.' 
Pa. 5

$\begin{array}{lllll}\hat{I} & \text { sun } & \text { zamé } & \text { anà } & \text { vio. } \\ 3 \mathrm{P} & \text { AUX.3P } & \text { never.NI } & \text { go.3S } & \text { away }\end{array}$

'They don't ever go away.'

papi

Pa.6

Î lu trobbën papì.

$3 \mathrm{P}$ him find.3P no more.NI

'They don't find him anymore.'/'They find him no more.'

For the following two negative indefinites, the pâ is optional and, when used, is emphatic.

nün

Pa.7

lh'èro (pâ) nün.

there-was.3S (NEG) no one.NI

'There wasn't anyone.'/'There was no one.'

rién

Pa.8

Â fai (pâ) rién.

${ }_{3} \mathrm{~S} \quad$ do. $3 \mathrm{~S}$ (NEG) nothing.NI

'Je does nothing. / (He doesn't do nothing. \{emphatic\})'

Negative Imperatives

In negative imperatives in Patouà, the position of the negative particle relative to the verb does not change with the co-occurrence of pronominal clitics, i.e., it follows the verb AND any cliticized pronouns in keeping with the normal paradigm for forming imperatives-positive or negative.

Pa.9 (Pons, C.)

Mûtrà-nû-lî!

show.IMP-us-them

'Show them to us!'

Pa.Io

Parlo-li-nén pâ!

speak.IMP-to.them-about.it NEG

'Don't talk to them about it!'

Negation in interrogatives with inversion

In Patouà, interrogative sentences can be formed by inversion. Their negative counterparts are negated by placing the $p \hat{a}$ after the inverted pronoun, yielding V-PRO $p \hat{a}$.

Pa.II

a) Vënê-tü?

Come.2S-2S-(Q)

'Are you coming?' 

b) Vënê-tü pâ?
Come.2S-2S-(Q) NEG
'Aren't you coming?'

Pa.I2

Î vénën-lò pâ?

3P come.3P-3P NEG?

'Are they not coming?'

Pa.I3

Â di-lò pâ rién?

3S say.3S-3S.Q NEG nothing.NI

'He isn't saying anything?'

Patouà

As a sidenote, we also find evidence of the pleonastic negative in

Pa.I4 (Pons, T.)

Ai tant dë vaccia cum (tü n'â) tü.

IS as.many PART cow.P as (2S EXPL-have.2S) $2 \mathrm{~S}$.

'I have as many cows as you (do).'

\section{Québécois}

Lastly, we have an interesting note on Québécois, which has lost its pre-verbal negative marker. In relation to French, we can see that Québécois has evolved into the next stage of Jespersen's cycle where the post-verbal particle now stands alone as the only negative marker.
Q.I (Riverin)
I didn't go to school today.
Q.2
$\mathrm{Y}$ parle pas jamais.
${ }_{3} \mathrm{~S}$ speak.3S NEG never.NI
'He never speaks.'

Chu pas allé à l'école aujourd'hui.

Be.IS NEG go.PPL to ART-school today.

\section{CONCLUSION: \\ THIS IS NOT AN INTRODUCTION}

In conclusion, we found that Zanuttini's generalizations, although true for several RL, cannot be applied to all. Even if some languages strategically fit into one of her three negation-groups, they did not always act in accordance with her predictions. We felt that she had a more clearcut typological claim for Group I, left room for too many exceptions in Group 3, and barely addressed Group 2. We also faced some difficulties in culling enough examples in various language varieties to make strong claims either for or against some of her arguments. In general, linguistic resources for less commonly spoken Romance languages are inaccessible outside of the region in which they are spoken. We based a good portion of our original proposal on native speaker informants. Unfortunately, due to the nature of fieldwork and working with informants, we did not get as much returned data as we had hoped. Due to the lack of relevant data, we 
could not find any substantial trends for Group 2 regarding Zanuttini's generalizations, which we had hoped to do.

\section{Works CiTED}

Bernini, G., \& Ramat, P. (I996). Negative sentences in the languages of Europe: A typological approach. Berlin; New York: Mouton de Gruyter.

Espinal, M.T. (I99I). Negation in Catalan. Some remarks with regard to no pas. Working papers in Catalan linguistics, 1, 33-63.

Espinal, M. T. (2000a). Expletive Negation, Negative Concord, and Feature Checking. Working papers in Catalan linguistics, 8, 47-69.

Espinal, M.T. (2000b). On the semantic status of $n$-words in Catalan and Spanish. Lingua, 1000, 557-580.

Giannakidou, Anastasia. (2002). N-words and negative concord. (unpublished) The Linguistics Companion. Oxford: Blackwell.

Herburger, E. (200I). The negative concord puzzle revisited. Natural Language Semantics, 9, 289-333

Hirsch, E. (I978). Provenzalische Mundarttexte aus Piemont

Jespersen, O. (I992). The Philosophy of Grammar. Chicago: University of Chicago Press.

Kim, J. (I995). The grammar of negation : A lexicalist constraint-based approach.

Lepschy, A. L. \& Lepschy, G. C. (I977). The Italian language today. London: Hutchinson.

Matos, G. (I999). Negative concord and the scope of negation. Working papers in Catalan linguistics, 7, I75-90

Morvan, C. (2008). Personal communication with Bryan Fleming

Muller, C. (I99I). La négation en français : Syntaxe, sémantique et éléments de comparaison avec les autres langues romanes. Genève: Droz.

Poletto, C. (2000). The higher functional field: Evidence from northern Italian dialects. New York: Oxford University Press.

Pons, C. R. (I990). Language Death among Waldensians of Valdese, North Carolina. Unpublished PhD, Indiana University, Bloomington.

Pons, T. G. (I973). Dizionario del dialetto valdese della val germanasca (Torino). Torre Pellice: Collana della società di studi valdesi.

Price, S.,. (I990). Comparative constructions in Spanish and French syntax. London; New York: Routledge.

Privitera, J. F. (I998). Basic Sicilian : A brief reference grammar. Lewiston, N.Y.: Edwin Mellen Press.

Riverin, P. (2008). Personal communication with Bryan Fleming, [text message from 24 April 2008].

Rowlett, P. (I998). Sentential negation in French. New York: Oxford University Press.

Zanuttini, R. (I997a). Negation and clausal structure: A comparative study of romance languages. New York: Oxford University Press.

Zanuttini, R. (I997b). Negation and verb movement. In L. M. V. Haegeman (Ed.), The new comparative syntax (pp. 2I4-). London; New York: Longman. 